\title{
THE EFFECTS OF MARGINAL NEIGHBORHOODS ON THE URBAN ECONOMY AND CIVIL ENGINEERING (CASE STUDY: AMIRIYEH REGION OF SHAHRIAR CITY)
}

\author{
H. Qaseminia and M. Ahmadi ${ }^{*}$ \\ ${ }^{1}$ Department of Urban Planning, Share-Qods Branch, Islamic Azad \\ University, Tehran, Iran
}

Published online: 15 May 2016

\begin{abstract}
Today, issues related to economy and urbanization are of fields that both in macro and micro dimensions, is the title of many studies of researches related to the urban and urban economy. Therefore, in this study aimed to investigate factors affecting the urban economy, and studied and explained the role of factors such as economic attraction, the urban size and shape, the city, the abnormalities, unemployment, lack of services, equipment and false jobs in the urban and in this regard, with providing multivariate model using fuzzy AHP, the effect of each factors listed in the study areas examined. The results of this study suggested that of the economic criteria, the urban size and shape, the criteria of construction and supply of housing with average turnover investment weighting 4.25 , the criteria of urban expansion with the average investment security 2.94 and land use, with the average investment security 2.64, were of measures that had the greatest impact with regard to economic aspects as well as the urban size and shape. Also, among the criteria of rising unemployment, lack of services and facilities, false jobs and raising anomalies, the highest mean has dedicated to lack of services and equipment (uncontrolled increase of urban population $=1.43$ ) that represents the high impact of suburbanization in uncontrolled increase in urban population and as a result the lack of services and equipment, followed by rising unemployment and increasing poverty and therefore false jobs.
\end{abstract}

Author Correspondence, e-mail: ahmadi.m@yahoo.com

doi: http://dx.doi.org/10.4314/jfas.v8i3s.179 
Keywords: suburbanization; urban economics; urban development; AHP method.

\section{INTRODUCTION}

Along with the rapid development of urbanization, marginalization spread also in most urban areas of the world and urban poverty and the large differences among urban neighborhoods were of the main causes that motivation creates the first sociological analysis of urban life. Not surprisingly, the first and most important sociological studies and theories about the conditions of today urban life was started in Chicago, a city that is distinguished by amazing pace of development and very clear inequality (Giddens, 2008). The rapid growth of urbanization in developing countries has led to increase in urban poverty and this growing phenomenon, has created many problems for the countries. So that one of the most important social problems of these countries is marginalization and its growing trend (Hadizadeh, 2004). On the other side, study of rural migration statistics in Iran shows that during the past few decades with the gradual breakdown of the agriculture traditional system and replacement of urban- industrial system, range of rural population motion has increased. This process increased after rural migration land reform, and became a social problem. Excessive and uncontrolled rural-urban migration can have adverse effects for the changes in the cortex of the urban population, become rural to urban workers (rural proletarianization), the emergence of severe acute unemployment, increase of false jobs, lack of adequate facilities and utilities for urbanization, the morbidly growth of urban areas and the emergence of suburbia are of the adverse consequences of immigration in urban areas. The most important result of rural migration to the cities is slum formation and marginalization. So that urban marginalization is mainly rural migrants. Of its consequences can mention to increase in crime, delinquency, the emergence of hidden unemployment, activity among other unofficial economic sectors that are of other marginalization consequences (Taghavi, 1993). In recent years the uncontrolled and unplanned migrations from all over the country to the town of Shahriar caused many problems for this city. That one of the most important of them is housing nonprofessional and low-income persons in the city's suburban areas. These people may have not ability to settle in the main space of the city and have been pushed to the suburbs limits. According to Shahriar location that is near the metropolis of Tehran and Karaj, it is anticipated that the process of migration will continue in the coming years and its consequences have followed the event of unemployment, lack of services and facilities, false jobs and especially marginalization. Considering the adverse consequences that the excessive and uncontrolled migration have created in large cities and especially in Shahriar, the more accurate understanding of the 
causes and consequences of this phenomenon is of particular importance. By providing the results of this research to urban planners, it is possible to reduce the adverse effects of economic and unplanned migration to the city of Shahriar in order to take the appropriate action. The main aims of this study were To review and analyze the impact of migration on the formation and creating marginal neighborhoods and to recognize the economic impact on the city, and study the effect of urbanization on urban economic size and shape attractions of the city and investigating the effect of marginalization in increasing unemployment, lack of services and facilities, false jobs and increased abnormalities in urban areas.

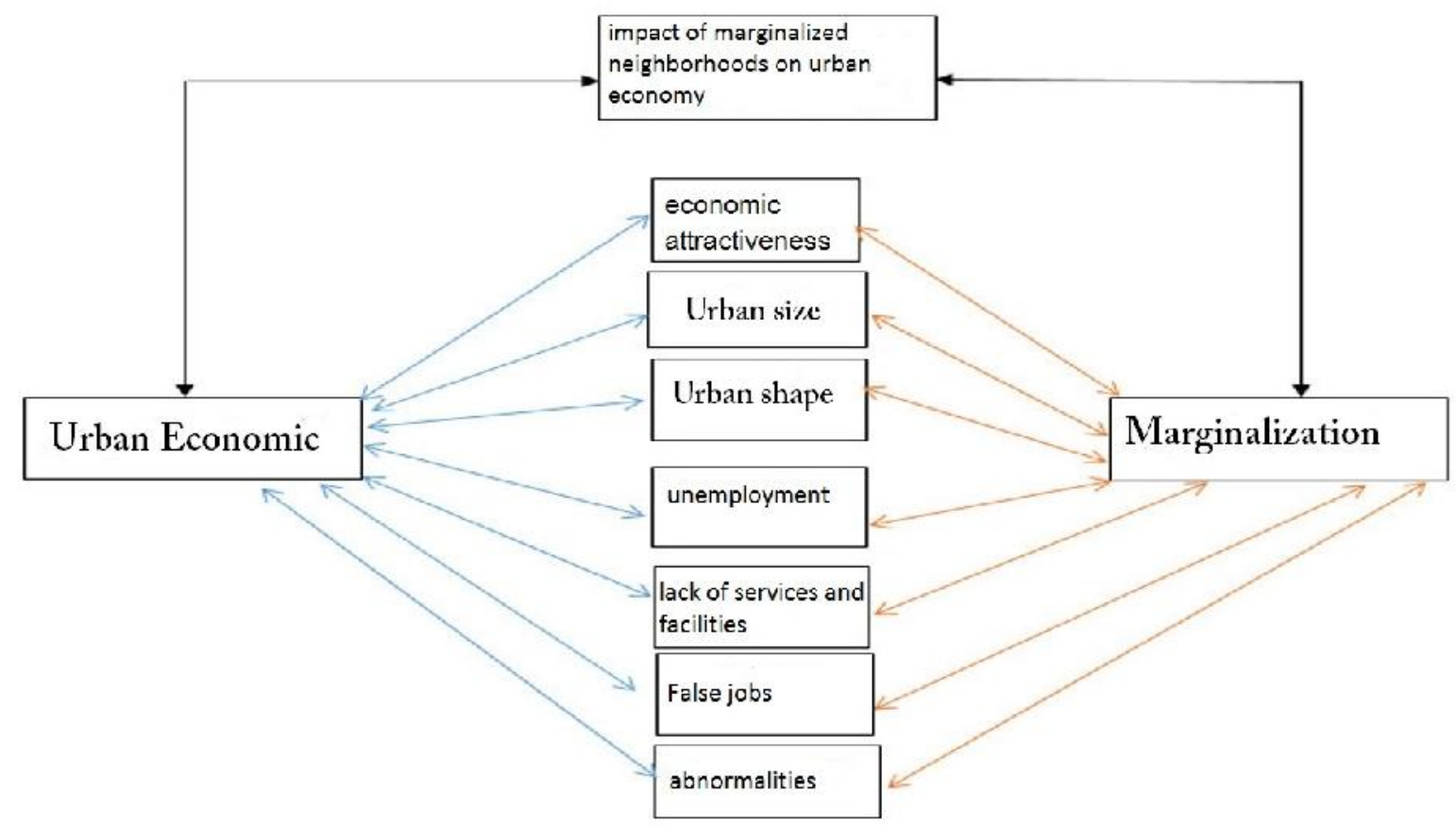

\section{METHOD AND MATERIALS}

The methodology of this study was combined method including systematic approach, descriptive and analytical method and was an applied research. According to the independent variables including marginalization and dependent variables including urban economy, size, shape, population density, economic activity and the accumulation of urban capital of Shahriar were investigated and examined the effects of these variables on urban economic variables. Analytical Network Process method was used to achieve the effect of immigration components on the urban economic components.

\section{THEORETICALLY, LITERATURE AND CONCEPTS}

The United Nations has defined immigration in its population dictionary as a form of geographical and time mobility that occurs between two geographical units. This geographic 
mobility is changing of residence from place of origin or departure point to arrival. This kind of migrations is called permanent migration and should be separated from other forms of population movements involving a change of permanent residence place (Kalantari, 2004). Also the definition marginalized is settlements within or adjacent to urban (especially large urban) with poor physical texture and mainly is self-grower comprising residential units that have been constructed without building technical principles (although with conventional materials) and have no official license. Most of its residents are of urban low-income groups with little background of urbanism that face by social impairments and urban unofficial employment that depend on them (Sarrafi, 2004). In definition of economy also states that it is moderation and avoidance of extremes in everything. According to the definitions of the economy, economists have offered various definitions. Jean-Baptiste in 1803, along with distinguishing the economics science of its use, defines it in public policy, as a science of production, distribution and wealth consumption (Diamond, 2008). Also, the concept of marginalization shows periphery economic or social issues and suggests that people live "outside the system". An important issue in this context is the impact of urban land use in social and economic stratification (Papeli Yazdi, 2003; Taherkhan, 2002). Unfavorable Works and outcomes of immigration in less developed countries in case of social and economic structures led to villagers to obtain better living opportunities to migrate from rural areas to urban areas (Zanjani, 2002). cultural exchange between different ethnic groups are in countries affected by dominant political migration get out of the routine and the culture of the immigrants on natives becomes a kind of domination (Zanjani, 2002). Prejudices about immigrants commit more delinquent behaviors destroys, moderates nationalism indulgence and leads to a kind of communal social life (Razavian, 2003). Discovering the inequalities in this respect that are caused by the inappropriate distribution of resources, are considered by urban planners and urban planning theorists have been forced to provide assumptions about the rise of inequality. (Papal Yazdi, 2003). The immigration process with income approach is expectations or permanent, in which expected revenue is depends on pay wages and the probability that can obtain employment (Bawi, 2006). Based on the perspective of the political economy of space, in the process of rapid and heterogeneous urbanization parallel to the unbalanced economic growth, income inequality increases and structural imbalances in society accelerate. In this view, attentions are paid to creating suburban areas and try to identify root problem (Bawi, 2006; Haj Yousefi, 2004). Additionally, imbalances in the suburbs also reflected in the use of space and makes the urban low-income groups to live on the fringes of cities by force (Pourahmad, 2008, Nazarian, 2006). Meanwhile, rural wage 
increases lead to reduce migration and by increasing urban wage to rural wage migration increases (Karimi Hasinjeh, 2008). Two factors are considered to explain the reasons for emigration movement including the factors and recession factors. On the other hand marginal areas physically have inconsistent differentiation with other urban areas and have undesirable situation (Hataminejad, 2004; Ghorbannia, 2002; Barabadi, 2006; Amkachi, 2003; Shokuie, 2000). In this regard, David Harvey believes that only by eliminating the mechanisms governing land use system can prevent the formation of ghettos of poverty and explaining the most important mechanisms, feedback externalities, migration content, finally would be able to analyze the consequences of immigration in this field (Dhas, 2010). Yan et al., 2015 in an article entitled "The urban economy based on neural network" have addressed the urban traditional evaluation method of economy for the lack of urban amenities. They established a new evaluation index and proposed a system evaluation and urban economy decision-making (Xia et al., 2014). Harstad, 2014 in an article titled, "imitation or innovation and Cooperation in urban economic innovation strategy" presented how innovation strategy reflects the density, diversity in urban places. Companies in Norway margin of four large urban area in general, had a greater commitment to their work and development than their urban counterparts (Sharma et al, 2014). Studies have evaluated the economic positive role of women in enhancing the values and long term strategies and in some fields including health and education.

\section{FACTORS AFFECTING MARGINALIZATION AND ITS REFLECTION}

Based on the theory of political economy of space, in the process of rapid and heterogeneous urbanization parallel to the unbalanced economic growth, income inequality increases and structural imbalances in society accelerates. In this view attention is paid to suburban areas reasons of creating and efforts are done to identify the root problem (Bawi, 2006; Haji Yousefi, 2004). Also, the effect of urban land use in social and economic stratification should be considered (Razavian, 2003; Potter, 2006; Pourahmad, 2008; Nazarian, 2006). Malthus was the first economist who proposed population issue and its transmission as an affecting variable on development issues, Malthus believed when the wages of workers are determined more than their living standards, they will soon marry and birth (Gillies, 2007).

\section{ECONOMIC AND POLITICAL FACTORS AND URBAN DEVELOPMENT}

Basically, the causes of urban development and prosperity are more economic than any other thing (Bahrain, 1992). Therefore it can be said that urban economy, is an important factor in 
the development of land. The destiny of an urban is determined with the amount and its production activity. So it is natural to count economic growth as synonymous with greater need for land, industry, commerce, housing, recreation, travel and or vice versa (Bahrain, 1999). Governments various aspects of urban development policy can be effective in the development of cities (Shakuie, 1995; Alinezhad Tayyebi, 2011; Divsalar, 2014).

\section{RELATION BETWEEN IMMIGRATION AND SUBURBIA}

Because of transferring the lifestyle from urban and rural environment to the suburbs close to the province, citizens instead of having culture of citizenship have quitted the former life and culture. They will be strange with new culture and cannot become a citizen in cultural point of view. Which their results; are apathy and lack of participation and responsibility in public life in the city. People are constantly interferes with each other and they hurt each other, have no intention of doing so (Alam, 2010). Diversity despite of having positive points, in some cases, because of various causes has led to cultural conflict. This contrast causes some people after a while leave living in neighborhood with brawl and creates many disputes between the residents of these areas (Kasagrand et al, 2009, quoted Divsalar, 1392).

\section{METHODS AND MATERIALS}

Methods of data collection in this research, was a combination of library-based methods, descriptive, field study by interview and fulfillment of questionnaires, study the documentation and classification of data. Amiriyeh area is one of the regions in Shahriar in Tehran Province. After studies and preliminary studies and use of statistical sources for this region from Shahriyar municipality and recognition of regions and locals and marginalization Amiriyeh areas, for selecting sample size, a number immigrants who migrated from these areas have been identified and interviewed and then proceed to complete the questionnaire. As all residents of this area were not immigrants and most of the immigrants living in these areas were already living in these areas, so they were not counted as immigrants that in recent years have been inhabited in this area. In this study, the sample size was all inhabitant of the Shahriar margin and the number of 371 of them was selected for the questionnaire using Cochran method. This questionnaire had 48 questions, and its main was to evaluate the factors affecting marginalized on urban economy (the economy, the size, shape, population density, economic activity, unemployment, lack of services and facilities, jobs and socio-economic factors and capital accumulation). 


\section{RESULTS}

According to the results of the questionnaire in the survey and analysis of the effects of creating marginal neighborhoods and understanding the economic impact on the city could be said that the phenomenon of creating marginal neighborhoods was effective on the urban economic

variables.

However, these effects may be due to the results in dimensions such as recession and uncontrolled increased urban sprawl and consequently creating poverty, lack of construction and supply of housing, reduce the visual qualities of urban spaces, and increasing uncontrolled urban level.

Table 1. Calculation of components matrix of urban economic attractions, size and shape

\begin{tabular}{|c|c|c|c|}
\hline Criteria & $\begin{array}{l}\text { Wage } \\
\text { level }\end{array}$ & $\begin{array}{l}\text { Circulating } \\
\text { Investment }\end{array}$ & $\begin{array}{l}\text { Investment } \\
\text { Security }\end{array}$ \\
\hline $\begin{array}{l}\text { Visual quality of urban } \\
\text { spaces }\end{array}$ & 0.15 & 0.11 & o 38 \\
\hline structure of the tissue space & 0.74 & 0.94 & $\begin{array}{l}038 \\
0=7 \\
0=7\end{array}$ \\
\hline $\begin{array}{l}\text { physical quality of urban } \\
\text { space }\end{array}$ & 0.28 & 0.02 & o. 27 \\
\hline Urban expansion & 1.1 & 2.0 & $\begin{array}{l}012 \\
z^{194}\end{array}$ \\
\hline Land use & 1.92 & 1.47 & 2.94 \\
\hline $\begin{array}{l}\text { Construction and housing } \\
\text { supply }\end{array}$ & 2.47 & 4.25 & $\begin{array}{l}2.97 \\
2.64 \\
105\end{array}$ \\
\hline
\end{tabular}

According to Table 1 it can be said that among urban economic, the size and shape criteria, the criteria of urban expansion with investment security with a mean of 2.94 and land-use with investment security with a mean of 2.64 , and also the construction and housing supply criteria with investing in flow weighted average 4.25, are measures that had the greatest impact with regard to economic aspects as well as the size and shape of the urban. 
Impact of marginalization on Economic attractiveness, and urban shape and size

Construstion and supply ot hnusing

linnd us:

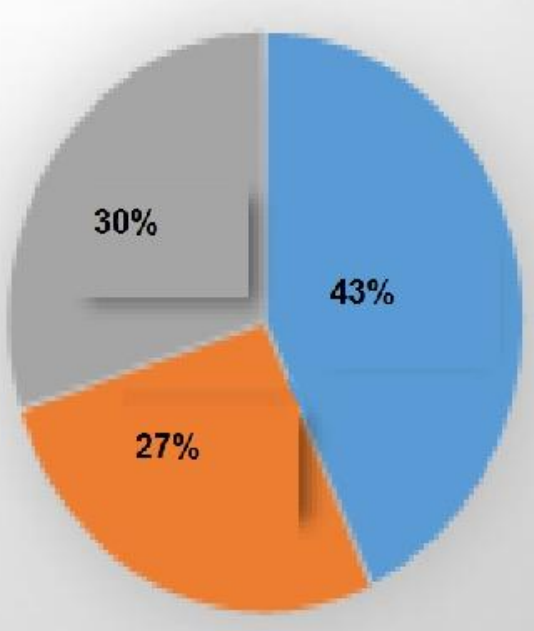

Fig.1. Comparative matrix of criteria and criteria with high weighing regarding the effects of the marginalization on urban economic, shape and size attractions

As can be seen in Fig 1, housings construction criteria by of weight (43\%) allocated most effects of marginalization among urban economic, size and shape criteria.

Table 2. Calculation of matrix of rising unemployment, lack of services and facilities, false jobs and increased abnormalities components and Marginalization

\begin{tabular}{c|c|cc|c}
\hline $\begin{array}{c}\text { criteria } \\
\text { Anomalies } \\
\text { (poverty) }\end{array}$ & $\begin{array}{c}\text { unemployment } \\
\text { (stagnation) }\end{array}$ & $\begin{array}{c}\text { lack of services and facilities } \\
\text { (uncontrolled increase of } \\
\text { urban population) }\end{array}$ & $\begin{array}{c}\text { False jobs } \\
\text { (households low } \\
\text { income) }\end{array}$ \\
\hline marginalization & 1.03 & 1.20 & 1.43 & 0.83 \\
\hline
\end{tabular}

According to Table 2, As can be seen from the criteria of rising unemployment, lack of services and facilities, false jobs and raise of anomalies, the highest allocated to mean lack of services and equipment (uncontrolled increase of urban population, mean=1.43). Which reflects the high impact of suburbanization on a steep rise in urban population and as a result, the lack of services and facilities followed by rising unemployment and therefore increasing poverty and false jobs. 


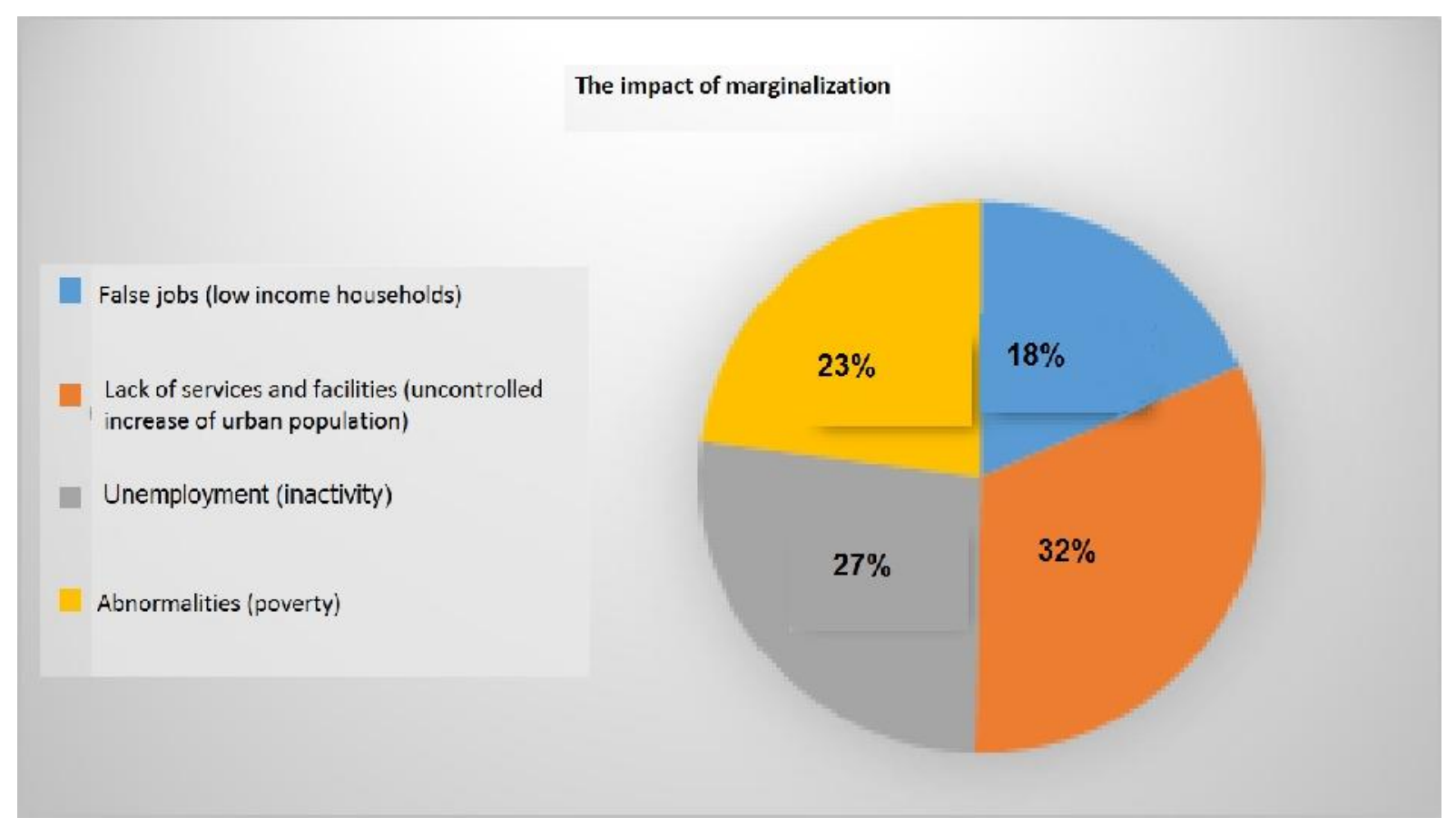

Fig.2. comparable matrix of effect of marginalization on the criteria with high weight regarding to rising unemployment, lack of services and facilities, false jobs and increased abnormalities

According to Fig. 2 as clearly significant, the highest percentage of weight can be allocated to the lack of services and facilities (an uncontrolled rise in the urban population=32\%).

Table 3. Calculation of matrix of effects of factors such as rising unemployment, lack of services and facilities, jobs and increased abnormalities on the urban economy

\begin{tabular}{|c|c|c|c|c|c|c|c|}
\hline criteria & $\begin{array}{l}\text { drop } \\
\text { househol } \\
\text { d income }\end{array}$ & $\begin{array}{l}\text { wag } \\
\text { e } \\
\text { level }\end{array}$ & $\begin{array}{l}\text { uncontrolle } \\
\text { d urban } \\
\text { level }\end{array}$ & $\begin{array}{l}\text { visual } \\
\text { qualit } \\
y \quad \text { of } \\
\text { urban } \\
\text { spaces }\end{array}$ & $\begin{array}{l}\text { constructio } \\
\text { n and } \\
\text { housing } \\
\text { supply }\end{array}$ & $\begin{array}{l}\text { Povert } \\
\text { y }\end{array}$ & $\begin{array}{l}\text { recessio } \\
\mathbf{n}\end{array}$ \\
\hline $\begin{array}{l}\text { Urban } \\
\text { Economic } \\
\text { s }\end{array}$ & 0.48 & 0.58 & 0.47 & 0.73 & 0.67 & 0.69 & 0.58 \\
\hline
\end{tabular}

According to Table 3, the visual qualities of urban spaces with weighted mean of 0.73 , followed by poverty component with the mean of 0.69 , construction and housing supply with 
the mean of 0.67 , and depression and wage level (mean=0.58) respectively had the most effective changes in the urban economy.

\section{DISCUSSION AND CONCLUSION}

According to the results obtained from the evaluation of data, it can be said that among the economic criteria and the urban size and shape, the criteria for urban expanding with urban investment (mean= 2.94), land-use with investment security (mean=2.64) and also construction and housing supply with investing in flow weighted average (mean=4.25) are of the most effects in relation to economic aspects and also urban shape and size. The results proved research assumptions and showed that marginalization had effective on urban economic, shape and size. The results can be interpreted as, development of economic facilities regarding to environmental issues and social justice are possible. Marginal neighborhoods where the uncontrolled extension has led to the gap and serious environmental problems and the development path toward social and environmental aspects are valued less than economy. The lack of attention to this problem can have a significant impact on urban economy attractions. The lack of attention to this problem can have a significant impact on urban economy attractions. Because the reduction in construction costs in suburban especially marginal neighborhoods, increase the desire of investors to invest in this sector. So, in this section of urban areas, the reduction of land price, low wages, construction services, have led them to this section of the city. Therefore, led to reduction of safe and desirable housing supply and disturb the urban shape, geometry and size. Because by daily development of urbanization, human life concepts related to sustainable development have entered to area of marginalization. Urban sustainable development is a new view toward social justice, environmental and space to the city. High density causes problems in cities, however, this strange and unprecedented density of population and a public need to attract basic resources have led to abnormal utilization of local resources and exploiting the resources of the neighborhood. The effects of this development with remained unpredictable waste continue and pollutions, diseases and different types of new marginal life is the new product of this development. But sustainable urban development as a part of sustainable development is based on the rational use of natural resources. In this kind of four issues including development, environmental, economic and social terms will be together. Therefore, this urban sustainable is the product of development process that allows the promotion of lifelong health arising from socio - economic and ecological of the urbanand this subjectivity and objectivity and action has made it possible. According to the results, among the criteria of 
rising unemployment, lack of services and facilities, false jobs and raise the anomalies, the highest mean allocated to criterion of lack of services and facilities (uncontrolled increase of urban population, mean=1.43). It showed the high impact of marginalization in increase of uncontrolled urban population and as a result shortage of services, facilities and as a consequence increase of unemployment, poverty and false jobs. These issues create beds for creating and occurring social problems, poverty, and cultural anomalies especially paving the way for the emergence of social problems, poverty and crime, especially crimes. Marginalization has effect in all spheres of public life of immigrants and native people and creates changes in population distribution. Because of the relationship between indigenous groups and immigrant groups that have more diverse social damages and increased opportunity for crime and criminality, breaking the law will be created. Of the other effects of marginalization on urban economic with respect to the obtained results in social service delivery criteria it can be said that, population growth in the suburbs affects effective cost and the nature of social and welfare services in urban areas. Population pressure resulting from immigration to urban fringe areas is evident. In most cases, this concept influences the classification of health, education and housing and led to rapid population growth in the suburbs and increase of health services. Urbanization makes it difficult to provide the current medical facilities in providing services to them. According to the results of other effects on marginalization and its expanding on urban economic are urban size and shape. Because of the speed of population growth on one hand and the lack of financial resources on the other hand and creation of construction offenses, sometimes added building, municipalities, as the main source of urban management and urban planning and management for conducting projects need to have income sources tut providing income from which way and with which method, and style is a big challenge.

\section{SUGGESTIONS}

With regard to the spread of suburban areas in most Iranian cities, especially large cities, it is impossible to organize physical state intervention in these areas and in case of government intervention, urban management organization, very much financial resources are necessary. Therefore, organizing approach based on empowerment of residents as strategic policy institutions has been located on municipal managers' agenda. The nature of the empowerment strategy is based on the perspective of poverty reduction and is gone based on sustainable human-centered development, with emphasis on the participation of citizens. Public participation, planning with the cooperation of the people, decentralization in government 
decision making, the recognition of social groups and capacity of local management are of the principles and dimensions of empowerment approach and at the macro level and policymaking are suggested that:

1. The first and the most important strategy at the macro level to eliminate and prevent of marginalization is adjustment for regional inequality and disparities between urban and rural adjustment.

2. In view of the poor level in urban planning.

3. In consideration of the marginalized population as a citizen of the institutions and urban organizations particularly municipalities.

4. The establishment of a department and organization empowerment of the marginalized

5. Providing right to security of housing and housing tenure.

\section{REFERENCES}

[1] Alam, Shaista (2010), 'Globalization, poverty and the environment degradation: Sustainable development in Pakistan' Journal of Sustainable Development, Vol. 3, No. 3, September, 114.

[2] Amakchi Hamideh. 2003. Law and legal instruments affecting on projection of population and urbanization, Tehran University Press.

[3] Arthur M. Diamond, Jr. (2008). "Science, economics of", The New Palgrave Dictionary of Economics, 2nd Edition, Basingstoke and New York.

[4] Bahraini Seyed Hossein. 1999. The process of urban design, Tehran University Press.

[5] Bawi Javad. 2006. Organizing suburbanites of Ahvaz city areas with emphasis on the region of Mallashiyeh, Master of Science thesis, Islamic Azad University.

[6] De Haas, Hein (2010). The internal dynamics of migration processes: A theoretical inquiry. Journal of Ethnic and Migration Studies, 36(10): 1587-1617.

[7] Diamond, Jr. (2008). "Science, economics of Backhouse, Roger E., and Steven Medema (2008). Economics.

[8] Divsalar Abdolrasool. 2016. Cultural diversity, human rights and human security approach, cross-cultural studies Journal: Volume 10, Issue 24.

[9] Ershad Farhang, Hazbavi Aziz. 2006. examining some of the motivations tend to Bronk Vechy of Ahvaz, "Iranian Journal of Sociology, 6(2): 107-120.

[10] Giddens Anthony. 2008. Sociology, Hassan Chavoshian, Tehran, Ney.

[11]Gillies Malcolm. 2007. Economic development, translated by Gholamreza Azad (Armaki), Ney publication, second edition, Tehran. 
[12] Hadizadeh Maryam. 2004. Marginalization and guidelines for organizing in the world, 43 and 44, Andisheh Hozeh publication.

[13]Haj Yousefi Ali. 2004. Urban margins and the process of its development, before the Islamic revolution, Seven City Journal, third year, Issue 42.

[14]Harvey David. 1998. Social justice and urban, Translated by Farrokh Hesamian. Publication of processing company.

[15]Hataminejad Hossein. 2004. The world's informal settlements, municipalities Magazine, $5(50)$.

[16] Herstad, Sverre J. mitate, or innovate and collaborate? On innovation strategy choices in the-urban-economy,-2014, http://wp.circle.lu.se/upload/CIRCLE/workingpapers/201508_Herstad.pdf

[17]Hiebert, Daniel and Rath ,Janand Vertovec ,Steven,2014 " Urban Markets and Diversity: Toward a Research Agenda "Max Planck Institute, Herman-Föge-Weg 11, 37073 Göttingen, Germany.Website: www.mmg.mpg.de.

[18] Kalantari Khalil. 2004. Assessment of rural development in the city of Turbat Hydyh, municipal of Torbat-e-Heydarie.

[19] Karimi Hasanijeh Hossein, Abedi Alireza. 2008. Migration and changes in agricultural productivity, the sixth conference of agricultural economics of Iran, Boom sazeh publications (databases Civilica) senior, Islamic Azad University, Najaf Abad branch.

[20]Nazarian Asgar. 2006. The metropolitan and its spatial reflection (case study: Tehran), Quarterly of territory geographical, year second, Issue 7.

[21] Potter Robert B, Seli Loid Eyouner. 2006. A city in the developing world, Translated by K. Irandoust.

[22] Pourahmad A. 2008. The scope and philosophy of geography, Tehran University press.

[23] Razavian Mohammdtaghi. 2003. Urban land use planning, Monshi publication.

[24] Sarrafi Mozaffar. 2004. Reviewing with the characteristics of the spontaneous settlement in Iran, in search of empowerment strategies, urban and informal settlements, marginalization and informal settlements Proceedings, vol. 1, Tehran University of Social Welfare and Rehabilitation Sciences.

[25] Shakuyi Hossein. 1995. New views in urban geography, Samt publication.

[26] Shakuyi Hossein. 2009. A new thought in philosophy, geography, Volume I, Gitashenasi publication. 
[27] Sharma, K.C. and Lalita Devi," Work time allocation and valuation of women' contribution in household activities in the urban economy of Himachal Pradesh",DOI: 10.5958/0976-4666.2014.00044.8

[28] Taghavi Nematollah. 1993. Theories of migration, Tabriz: Sotoodeh publication.

[29] Taherkhani Mehdi. 2003. Identifying factors affecting rural-urban migration, Madras journal, summer, Volume 6, Number 2.

[30]Xia Yang-qi \&Yan, Pang. 2014"evelopment of economy and society of chang-zhu-tan urban-agglomerationAnalysisaboutthedevelopmentforecast https://books.google.com/books?isbn=1138026549

[31] Yan.L and Zhang L.P. "Research on Evaluation Model of the Urban Economy Based on Rough Set and Neural Network", 2015. International Conference on Computer Information Systems and Industrial Applications (CISIA 2015) pp (433-436).

[32]Zanjani Habibollah. 2002. Immigration, the study and compilation of Humanities, University, Tehran, First Edition.

\section{How to cite this article:}

Qaseminia H and Ahmadi M. The effects of marginal neighborhoods on the urban economy and civil engineering (case study: Amiriyeh region of shahriar city). J. Fundam. Appl. Sci., 2016, $8(3 S), 247-260$. 